92 | Muhammad Ismail, Relasi Ekonomi Global dan Komunitas Lokal.. ..

\title{
Relasi Ekonomi Global \\ Dan Komunitas Lokal Dalam Pembangunan (Studi Kasus Konflik Makam Mbah Priok)
}

\author{
Oleh : Muhammad Ismail \\ Muhammad.ismail@uinjkta.c.id
}

Abstrac : Perkembangan ekonomni global telah membawa dampak positif dan negative, Indonesia bagian dari negaranegara berkembang yang mengalamai proses ekonomi global mendapatkan dampak tersebut.

Konflik perebutan lahan makam mbah Priok tahun 2010 antara Pelindo II adalah dampak dalam melaksanakan pembangunan ekonomi di era ekonomi global, yang hanya mementingkan nilai liberalism tanpa menghiraukan nilai-nilai lokal, konflik antara keduanya berdampak buruk dalam proses pembangunan di Tanjung, solusi damai merupakan jalan menuju pembangunan masyarakat Tanjung Priok

Kata kunci : Ekonomi global, Konflik, Pembangunan

A. Pendahuluan

Sejak berakhirnya perang dingin, dunia telah dilanda oleh suatu arus perubahan yang bersifat global. Perubahan demi perubahan, akan terus berlanjut dalam abad 21. Pembangunan di negara-negara berkembang pada umumnya sedang mengalami proses globalisasi.

Hal ini ber akibat bahwa proses pembangunan negara berkembang tidak bisa dilaksanakan sendiri. Beberapa negara berkembang, seperti Indonesia dan negara Asia Timur serta beberapa negara Amerika Selatan lainnya sudah menempuh proses pembangunan sehingga mengalami perubahan struktur ekonomi dan sosial yang cukup besar.

Pembangunan perekonomian Indonesia sangat terkait dengan ekonomi global dengan munculnya perusahaanperusahaan multinasional di Indonesia $^{1}$. Perubahan yang berlangsung ini menumbuhkan kekuatan-kekuatan sosial baru 
yang memerlukan penanganan dan kerangka kebijaksanaan pembangunan yang baru pula.

\section{B. Analisa relasi Teori Globalisasi dan Pembangunan}

Globalisasi diartikan dalam banyak pengertian oleh para pengamat dan ahli. Ashcroft, Griffiths dan Tiffin, misalnya, dalam buku Post-Colonial Studies: The Key Concepts mendefinisikannya sebagai "proses dimana kehidupan seseorang dan masyarakat lokal dipengaruhi oleh kekuatan-kekuatan ekonomi dan budaya yang beroperasi secara mendunia". ${ }^{2}$

Pada gilirannya wacana tentang globalisasi akan mengundang kontroversi dan polarisasi. Polarisasi tersebut adalah dua pandangan besar terhadap globalisasi, yakni kubu pro atau optimistis yang menganggap globalisasi sebagai peluang vis-a-vis kubu kontra atau pesimistis yang melihat globalisasi sebagai ancaman.

Globalisasi ekonomi sebenarnya telah terjadi sejak lama yakni sejak masa perdagangan rempah-rempah, masa tanam paksa (cultuur stelsel) dan masa dimana modal swasta Belanda dikembangkan pada zaman kolonial melalui buruh paksa. Pada ketiga periode tersebut hasil bumi Indonesia telah masuk ke Eropa dan Amerika. Selain itu, impor tekstil dan barang-barang manufaktur dalam bentuk sederhana telah berlangsung lama.

Perbincangan mengenai gagasan negara pascakolonial sangatlah menarik untuk dikaji dalam konstelasi permasalahan negara dunia ketiga saat ini. Terminologi Negara pasca colonial sendiri masih mengundang perdebatan teoritik dalam ilmu social baik sekala regional maupun internasional. Ada yang mengatakan negara pascakolonial adalah negara dunia ketiga dirunut dari alur sejarah yang muncul paska dekolonialisasi. Namun ada pula yang mengatakan negara pascakolonial adalah negara yang secara politik sudah merdeka, namun secara ekonomi masih terjajah. Adanya dua perspektif tersebut mendasarkan analisanya pada alur linearitas kolonialisme dengan paskakolonialisme yang pada umumnya melihat kondisi negara yang masih miskin dan penuh dengan ketimpangan.Cara pandang itu tidaklah salah, namun ada baiknya pula untuk 
melihat struktur formasi sosial yang terdapat dalam negara pascakolonial sehingga stigmatisasi negara miskin masih melekat dalam konteks kekinian. Dengan pemahaman globalisasi model lama, yang terjadi di negara-negara Afrika, mereka membayar mahal dengan kolonialisme yang masuk ke negara-negara mereka. Dalam penelitian Englebert di negaranegara Afrika mengatakan :

"..I have shown that Africa has paid a high price in terms of foregone growth by failing in the early 1960s to question the state structures it inherited from colonialism, and have provided some clues as to why Africa counts so few "developmental" states. 3

Globalisasi ekonomi yang terjadi saat ini merupakan manifestasi baru dari pembangunan kapitalisme sebagai sistem ekonomi internasional. Dalam sector perekonomianlah paling merasakan dampak positif globalisasi. Perkembangan industri begitu pesat, perdagangan bisa terjadi lintas negara serta membuka pasar tenaga kerja internasional. Dengan diterapkannya perdagangan bebas maka produk dalam negeri dapat dipasarkan ke berbagai negara tanpa bea masuk. ${ }^{4}$. Selain berpangaruh terhadap perdagangan antar negara, globalisasi juga mendorong terbentuknya lembaga-lembaga ekonomi dunia yang beranggotakan negara-negara di dunia. Seperti International Monetary Fund (IMF) dan World Trade Organization (WTO), sebagai organisasi dunia yang membantu mengatur laju perdagangan dan perputaran uang antarnegara. Globalisasi ikut berperan untuk membentuk perjanjian kerjasama perdagangan regional seperti Asia-Pasifik Economic Cooperation (APEC), Nort American Free Trade (NAFTA), Asian Free Trade Area (AFTA) dan adanya pembentukaan mata uang Euro sebagai mata uang bersama negara-negara di kawasan Eropa. Apalagi setelah adanya Masyarakat Ekonomi ASEAN (MEA) 2015 yang tidak lama lagi akan terealisir. ${ }^{5}$

Pembahasan mengenai globalisasi ekonomi sejatinya tidak terlepas dari pembahasan mengenai kapitalisme sebagai bagian penting dari globalisasi ekonomi itu sendiri. Hal demikian dapat dipahami karena kapitalisme tidak lain 
merupakan sistem perekonomian yang menyokong perkembangan arus globalisasi. Mansour Fakih menuliskan, "globalisasi sesungguhnya secara sederhana dipahami sebagi suatu proses pengintegrasian ekonomi nasional bangsa-bangsa ke dalam suatu sistem ekonomi global. Serta, kapitalisme global pada dasarnya merupakan salah satu fase perjalanan panjang perkembangan kapitalisme liberal, secara teoritis yang sebenarmya telah dikembangkan oleh Adam Smith. Dengan kata lain, kapitalisme global merupakan usaha atau suatu tahap dari kolonialisme negara-negara yang kaya terhadap negara-negara yang miskin atau yang sedang berkembang. Oleh karena itu, globalisasi muncul pada mulanya dari segi ekonomi suatu negara" .

Kapitalisme Global merupakan suatu perkembangan yang tidak bisa dihindari dan dicegah. Namun proses globalisasi telah menjadikannya budaya semua orang diperkenalkan secara sistematis dan intensif ke seluruh pelosok dunia. Era globalisasi yang berkembang dalam abad 21, memuat tantangan yang berbeda dari abad sebelumnya yang memuat nasionalisme, national state, politik nasional, ekonomi nasional dengan tekanan pada nasional dalam negara dengan perbatasan yang jelas. Memasuki era globalisasi, mengharuskan kita bersikap arif dan mampu merumuskan serta mengaktualisasikan kembali nilai-nilai kebangsaan yang tangguh dalam berinteraksi terhadap tatanan dunia luar dengan tetap berpijak pada jati diri bangsa, serta menyegarkan dan memperluas makna pemahaman kebangsaan kita.

Globalisasi merupakan suatu era yang kini mau tidak mau menjadi tantangan tersendiri bagi Indonesia. Banyak tantangan besar yang sebenarnya dihadapi oleh negara kita, termasuk rakyat didalamnya, untuk bagaimana bertahan hidup dan menjadi bagian yang bertahan di dalam proses globalisisasi kini.

Ekonomi global adalah perekonomian suatu negara yang terlibat secara global di negara-negara didunia didalam aktivitas perekonomian. Aktivitas ini dapat berupa perdagangan seperti ekspor dan impor barang dari dan keluar negeri. Indonesia adalah negara yang kini menjadi salah satu wujud nyata dari 
defenisi globalisasi sendiri, dimana Indonesia juga merupakan salah satu negara yang menjadi dampak bahkan pelaksana proses globalisasi tersebut. Indonesia adalah negara yang berhubungan baik dengan negara-negara lainnya karena melakukan perdagangan Internasional.

Indonesia adalah negara yang memiliki banyak hubungan secara internasional kepada negara-negara di dunia. Negara kita melakukan perdagangan secara Internasional baik itu melalui aktivitas ekspor maupun impor. Melalui aktivitas ekspor, Indonesia akan menjual dan mengirim produk hasil bumi dari negara Indonesia sendiri ke negara lain, seperti negara-negara di kawasan Asia dan juga ke negara-negara di luar kawasan Asia sendiri. Melalui aktivitas impor, Indonesia akan menerima atau membeli kebutuhan yang dibutuhkan oleh negara kita untuk menunjang kelanjutan kelangsungan hidup negara kita kedepannya. Lewat kedua aktivitas ini, Indonesia selalu berhadapan dengan Ekonomi secara global. Ekonomi yang tanpa ada batasan negara dan diperhadapkan dengan berbagai kondisi ekonomi secara global. Pembangunan perekonomian Indonesia sangat terkait dengan ekonomi global dengan munculnya perusahaan-perusahaan multinasional di Indonesia ${ }^{7}$

Aktivitas ekspor dan impor sangat berpengaruh besar atas pendapatan negara. Semakin tinggi aktivitas ekspor terhadap negara-negara lain, akan semakin tinggi pula penerimaan negara yang kita peroleh. Namun sebaliknya, semakin tinggi impor kita, maka semakin banyak yang perlu kita lunasi sehingga mengurangi penerimaan/pendapatan negara sendiri. Oleh sebab itu negara kita perlu bahkan harus meningkatkan kualitas ekspor barang-barang atau produk-produk bangsa ke luar negara, agar dapat meningkatkan pendapatan negara dan dapat memenuhi kebutuhan negara dan kesejahteraan rakyat khususnya.

Perkembangan kota merupakan tuntutan sekaligus jawaban dari perkembangan penduduk maupun kegiatan masyarakat perkotaan yang semakin sulit dikontrol sehingga sering menimbulkan persoalan-persoalan yang menyangkut persoalan terhadap kota itu sendiri (fasilitas, sistem dan area), maupun terhadap penduduk atau penghuninya dan pergerakan ekonomi sebagai penentu terhadap perkembangan tersebut (B. 
Karena perannya yang strategis di Indonesia menjadi sebuah impian sebagai pasar ekonomi yang menarik bagi ekonomi global karena penduduknya yang besar.

Secara umum, banyak hal positif yang dirasakan oleh negara Indonesia sendiri terkait dengan proses globalisasi yang sedang terjadi. Selain yang disebutkan diatas, banyak hal terasa jauh lebih mudah dari zaman-zaman dulunya. Seperti pengolahan faktor produksi, desain produk, pengangkutan hasil produksi, promosi dan penjualan, dan masih banyak lagi. Hal ini terjadi karena munculnya berbagai teknologi baru yang mendukung untuk memudahkan pekerjaan-pekerjaan dalam bidang tersebut. Munculnya berbagai teknologi dan berbagai media elektronik yang canggih menjadi jawaban atas perkembangan diberbagai bidang di negara Indonesia saat ini.

\section{Fenomena Relasi Globalisasi dalam Konflik perebutan Makam Mbah Priok antara Pelindo II dan Ahli Waris}

Jakarta sebagai kota metropolis, di depan system ekonomi global berada sejajar dengan kota-kota besar dunia lainnya, banyak perusahaan-perusahaan Global yang berkantor di Jakarta, seperti : PT. Cocacola, PT.Cemex Indonesia, PT. Cardic Express Nusatara dan sebagainya yang menunjukkan bahwa Indonesia sudah memasuki era pasar bebas sebagai ciri dari globalisasi. Perusahaan-perusahaan Mutinasional yang masuk ke Indonesia melihat pasar Indonesia sangat memungkinkan untuk membesarkan keuntungan usaha karena didukung jumlah pendudukanya yang sangat besar. Termasuk Pelabuhan Tanjung Priok saat ini sebagai investor pelabuhan peti kemas di Tanjung Priok adalah Hutchinson Port Holding dan terminal peti kemas terbesar yang dalam tahap pembangunan, yakni Terminal Kalibaru, Tanjung Priok, perusahaan asal Jepang, Mitsui \& co, Ltd (Mitsui) (Antara, 7 Oktober 2014). bahkan Direktur Utama PT Pelindo II (Persero) RJ Lino menegaskan, perpanjangan konsesi Jakarta Internasional Container Terminal antara PT Pelindo II dan Hutchison Port Holdings hingga tahun $2039 .{ }^{8}$

Pecahnya konflik sosial Tanjung Priuk tanggal 14 April 2010 lalu telah merenggut korban jiwa tiga orang, dan puluhan 
lainnya luka-luka, selain itu kerugian material yang ditaksir mencapai milyaran rupiah. Konflik tersebut terjadi antara massa dengan aparat Satuan Polisi Pamong Praja (Satpol PP). Aparat Satpol PP awalnya hendak melakukan pembebasan lahan di kompleks pemakaman Habib Hassan bin Muhammad Al Hadad alias Mbah Priuk yang diklaim tanah tersebut merupakan milik PT. Pelabuhan Indonesia II (PT. Pelindo II). Kompleks pemakaman Mbah Priuk yang disebut-sebut merupakan pendiri Tanjung Priuk itu berusia ratusan tahun, selama ini digunakan untuk tempat pengajian mingguan yang jumlah santrinya cukup banyak

Pada kasus konflik perebutan makam mbah Priok menjelaskan kepada kita bahwa Pelindo II sebagai perusahaan BUMN milik pemerintah yang sudah melakukan kerjasama dengan pihak MNC yaitu Hutchinson Port Holding dan Mitsui \& co, Ltd (Mitsui) tentu memilki keinginan untuk mengembangkan lebih bagus sesuai standar Pelabuhan Internasional dengan tujuan untuk mefasilitasi kapal-kapal yang melakukan aktivitas ekspor impor dapat lebih banyak.

Keinginan memperbaharui pelabuhan memang memiliki alasan kuat untuk dilakukan karena data statistik Kementerian Perhubungan tahun 2011, kapasitas pelabuhan di Singapura mencapai 29,9 juta TEUs, pelabuhan Laem Cha-bang Thailand berkapasitas 10,5 juta TEUs, sementara Tanjung Priok hanya mampu menangani 5,7 juta TEUs per tahun. Dalam hal ini, meski luas wilayah negara Singapura yang terkecil di Asia Tenggara, namun ia memiliki pelabuhan paling besar dan paling sibuk di kawasan Asia Tenggara. Dalam rangking dunia, Port of Singapore kerap berada di peringkat kedua \& ketiga sejak 2008. Port of Singapore juga terhubung dengan 600 pelabuhan yang ada di lebih 100 negara. Pelabuhan itu pun mengelola kargo minyak dimana Hampir 50\% minyak mentah dunia transit di Singapura ${ }^{9}$

Fenomena kebutuhan terhadap lahan cenderung terus meningkat yang merupakan akibat dari perkembangan ekonomi dan pertumbuhan penduduk. Pada gilirannya hal tersebut akan melahirkan gejala persaingan penggunaan lahan, yang sesungguhnya merupakan manifestasi dari berlakunya hukum 
permintaan (demand) dan penawaran (supply ). Hal tersebut dapat dipahami, mengingat lahan merupakan sumberdaya alam yang amat penting. Hampir semua aspek kehidupan dan pembangunan, baik langsung maupun tidak langsung berkaitan dengan permasalahan lahan.

Seiring dengan terjadinya pertumbuhan wilayah termasuk di dalamnya pertumbuhan kota, kebutuhan (demand) akan sumberdaya lahan cenderung meningkat. Sementara itu dilihat dari ketersediaannya dalam arti luasan lahan dalam batas administratif bersifat terbatas (in-elastic). Oleh karena itu dengan terjadinya perubahan struktur ekonomi, yang ditandai oleh perkembangan sektor industri, meningkatnya aktivitas dan ragam spesialisasi di luar bidang pertanian serta pertambahan jumlah penduduk yang antara lain disebabkan oleh adanya urbanisasi, diduga akan mengakibatkan terjadinya pergeseran pola penggunaan lahan, bahkan kuburan yang semestinya menjadi tempat orang meninggal telah menjadi tempat tinggal bagi orang perkotaan yang tidak mendapatkan lahan yang seharusnya $^{10}$

Kajian konflik antara perusahaan koorporasi di perkotaan yang di dukung oleh pemerintah dengan masyarakat memiliki berbagai sebab, analisa yang sering ditemukan dalam berbagai literature banyak disebabkan oleh kepentingan ekonomi dan politik. Konflik antara koorporasi dengan komunitas local setelah reformasi meningkat ${ }^{11}$, seperti konflik Perusahaan Kaltim Prima Coal, Newmont, Keian Equatorial Mining, Prima Lestari, Newmont Minahasa Raya, Freeport Indonesia, konflik banyak terkait dengan industry tambang dan migas.

System ekonomi global sudah menjadi bagian keharusan bagi negara-negara berkembang Globalisation in this sense can indicate both a process and a condition a tendency within the economy and other spheres, or the state of living in a globalised world

Jakarta merupakan Ibu Kota dan sentrum standarisasi pertumbuhan kota-kota di Indonesia, dan merupakan kota perdagangan dan jasa. Jasa Transportasi laut merupakan satu pilihan yang masih menjadi andalan bagi pergerakan ekonomi 
dunia. Pelabuhan Tanjung Priok adalah bagian yang terpisahkan sebagai pendukung pertumbuhan ekonomi Global karena banyaknya arus keluar masuk barang (ekport import) melalui jasa pelabuhan Tanjung Priok.

Pelabuhan Tanjung Priok berdiri di atas lahan $195 \mathrm{Ha}$, kondisi Pelabuhan Tanjung Priok semakin menurun karena keterbatasan lahan padahal desain Pemerintah Belanda, Pelabuhan Tanjung Priok hingga Cempaka Putih dan Sunter yang harus bersih dari pemukiman penduduk ${ }^{12}$ (Gunawan, 2013). Pembangunan Pelabuhan Tanjung Priok Internasional Modern sebagai wujud proses peningkatan ekonomi nasional di tingkat Global, karena nantinya bila pelabuhan modern ini bisa terwujud maka kapal-kapal besar yang selama ini bongkar muat di Singapura akan langsung ke Tanjung Priok.

Pengadaan lahan untuk mendukung Proyek Pelabuhan Tanjung Priok Modern terkendala oleh penolakan ahli waris dan masyarakat yang menyakini sebagian dari makam-makam yang dibebaskan oleh Pelindo II adalah makam seorang Wali Mbah Priok yang diyakini sebagai makam keramat. Maka konflik yang terjadi antara Ahli Waris didukung oleh masyarakat melawan Pelindo II didukung oleh Pemda DKI bersama Satpol PP dan beberapa Polisi serta TNI menjadi pemberitaan hangat di media massa.

Secara sosiologis Pemerintah (Negara) dan Pelindo II merupakan "bagian dari masyarakat yang memiliki Power, force dan juga authority untuk mengalokasikan sumber-sumber dan fasilitas dari system-sistem sosial"13. Untuk pemerintah dalam melaksanakan pembangunan ekonomi di era pasar bebas ini berharap mendapatkan pemodal yang mau bekerjasama, untuk itu hubungan Negara dengan koorporasi sangat terkait demi amannya proses produksi ekkonomi yang dilakukan ${ }^{14}$.

Konflik-konflik yang terjadi dalam masyarakat terutama di perkotaan merupakan konsekuensi logis dari hubungan antara masyarakat. Konflik di masyarakat bisa berlatar belakang agama, etnik, ekonomi, sistem politik yang represif, dan dominasi birokrasi.

Dalam kasus konflik anatar koorporasi dengan ahli waris makam Mbah Priok sebagai contoh adalah obsesi dari MNC 
ingin menyamai pelabuhan-pelabuhan di kawasan Asean , sementara tanah tidak bertambah dan minimnya tanah kosong yang terdekat dari Pelabuhan yang sudah ada, maka pengadaannya semakin sulit dan langka. Perluasan pelabuhan sudah dilakukan dengan memindahkan pemukiman-pemukiman warga yang ada di kawasan pelabuhan termasuk komplek pemakaman umum di Jalan Dobo yang di dalamnya terdapat makam Mbah Priok yang diyakini oleh sebagian masyarakat memiliki kekeramatan karena dianggap Wali. Pemahaman situasi social yang tidak memadai tentang tradisi tersbut, pemaksaan serta upaya penggusuran yang dilakukan mendapatkan perlawan yang keras dari masyarakat.

Konflik koorporasi dengan komunitas local terkait dengan nilai-nilai atau keyakinan menjadi hal menarik karena perbedaan pandangan tentang kepentingan tanah yang diperebutkan kedua belah pihak, penyelesaian konflik oleh Pelindo II dan Pemerintah DKI dengan pemaksaan atas dua pandangan yang berbeda ini dilakukan dengan kekerasan yang berakibat kepada kerugian material dan non material, maka diperlukan mekanisme baru dalam menyatukan pandangan pembanguan, sehingga kedua belah pihak akan mendapat solusi yang saling menerima, diharapakan dapat memberikan solusi bagi pembangunan. Dengan demikian koorporasi atau MNC sebagai bagian ekonomi global dalam melakukan aktivitas ekonomi mesti memperhatikan nilai-nilai local, supaya tidak terjadi perbenturan kepentingan.

\section{Simpulan}

Dari konteks relasi Ekonomi Global dan Masyarakat lokal pada kasus konflik perebutan makam Mbah Priok bahwa telah terjadinya perlakuan semena-mena oleh Pelindo II sebagi agen Ekonomi Global terhadap tradisi dan keyakinan masyarkat local yang sudah mengakar di masyarakat,

Maka diharapakan kedua kelompok Koorporasi (Pelindo II) bersama PEMDA DKI dan Ahli waris bertemu untuk melakukan penyelesaian permasahalahan keberadaan komunitas pengajian makam mbah Priok di tengah pusat aktivitas ekonomi 
global. Hal ini tentu diharapkan adanya jalan keluar yang baik keduanya nisa menerima. Koorporasi Global yang tidak melihat konteks nilai tradisi yang ada di masyarakat mengusirnya dengan kekerasan dari tengah aktivitas ekonomi global.

${ }^{1}$ Cucu Nurhayati, Sosiologi Industri, ( Jakarta: UIN Jakarta Pres, 2014), h 7

${ }^{2}$ Ashcroft; Gareth Griffiths; Helen Tiffin . Post-Colonial Studies: The Key Concepts, (London: Routledge, 2007), h. 29

${ }^{3}$ Pierre Englebert, (2000), Pre-Colonial Institutions, Post-Colonial States, and Economic Development in Tropical Africa, Vol. 53, No. 1 (Mar., 2000), pp. 7-36, Sage Publications, Inc, h.29

${ }^{4}$ Cucu Nurhayati, Sosiologi Industri, h. 9

${ }^{5}$ Fairuz Hasna Karimah dan Andira, Syaninta Alvi Andira, 2014, Kesiapan Sumber Daya Manusia Indonesia dalam menghadapi AEC 2015, Dialektika, UI

${ }^{6}$ Mansour Fakih, Analisis Gender dan Transformasi sosial, ( Jakarta: Insist Pres, 2008) h. 18

${ }^{7}$ Cucu Nurhayati, Sosiologi Industri, h. 10

${ }^{8}$ Kompas, 8 Agustus 2014

${ }^{9}$ dephub.go.id

${ }^{10}$ Purnawan Basundoro, Merebut Ruang Kota: Aksi Rakyat Miskin Kota Surabaya, (Surabaya, Marjin Kiri, 2013),h. 2.

${ }^{11}$ Dody Prayogo, Anatomi Konflik Antara Korporasi Dan Komunitas Lokal Pada Industri Geotermal Di Jawa Barat, Makara Seri SosialHumaniora, Vol 1, No 14 (2010) : 25-34

12 Sunaryo, Rony Gunawan, Perubahan Setting Ruang dan Pola Aktivitas Publik di Ruang Terbuka Kampus UGM, Humanisme dalam Realita Perancangan Arsitektur, UGM

${ }^{13}$ Conflict,. Internasional Encyclopedia of the social sciences ,1992, vol.3 dan 4, edisi ke 10.: 386

${ }^{14}$ Sitepu, Dewi Sinorata dan Anggraini, Silvia Dian, 2007, Fenomena Korporasi dalam Kotestelasi Internasional (Tinjauan Teoritis), Global \& Strategis, Th. 1 No. 3 , h. 5 


\section{REFRENSI}

Antara, Asing Kuasai Tanjung Priok dan Tanjung Perak, 7 Oktober 2014

Ashcroft; Gareth Griffiths; Helen Tiffin ,2007. Post-Colonial Studies: The Key Concepts London: Routledge

Dove, Michael R. 1988, The Real and Imagined Role of Culture in Development: Case Studies from Indonesia, Human Ecology, Vol. 16, No. 3, pp. 354-358

Fatton, R J Jr. (1992), Predatory Rule, State and Civil Society in Africa, Boulder and London: Lynne Rienner Publishers.pp. 561-587

Fikih,Mansour, (19990), Sesat Pikir Teori Pembangunan dan Globalisasi,

John W Creswell. (2003) Reseacrh Design.(terj.2009).Ahmad Fawaid, Yogyakarta.

Karimah, Fairuz Hasna dan Andira, Syaninta Alvi Andira, 2014,

Kesiapan Sumber Daya Manusia Indonesia dalam menghadapi AEC 2015, Dialektika, UI

KOMPAS, 08 AUGUST 2014

Mellos, Koula , 1978, Developments in Advanced Capitalist Ideology, Canadian Journal of Political Science, Vol. 11,No. 4 (Dec., 1978), pp. 829-861

Morgan, Earl Conteh, 2006, Globalization, State Failure, And Collective Violence : The Case of Siere Leone ,International Journal of Peace Studies, Vol. 11, No. 2, pp. 87-104

Neil Brenner, Global Cities, Glocal States: Global City Formation and State Territorial Restructuring inContemporary Europe, Review of International Political Economy, Vol. 5, No. 1 (Spring, 1998), pp. 1-37

Peter B. Evans,Predatory, 1990, Developmental, and Other Apparatuses: A Comparative Political EconomyPerspective on the Third World State, Sociological Forum, Vol. 4, No. 4, 
104 | Muhammad Ismail, Relasi Ekonomi Global dan Komunitas Lokal.. ..

Pierre Englebert, (2000), Pre-Colonial Institutions, PostColonial States, and Economic Development in Tropical Africa, Vol. 53, No. 1 (Mar., 2000), pp. 7-36, Sage Publications, Inc.

Riain, Sean O. 2000, States and Markets in an Era of Globalization, Annual Review of Sociology, Vol. 26 , pp. 187-213

Sitepu, Dewi Sinorata dan Anggraini, Silvia Dian, 2007, Fenomena Korporasi dalam Kotestelasi Internasional (Tinjauan Teoritis), Global \& Strategis, Th. 1 No. 3, 83107

Stiglitz, Joseph E, 2006, Making Globalization, New York, WW. Norton \& Company. Inc

Sunaryo, Rony Gunawan, Perubahan Setting Ruang dan Pola Aktivitas Publik di Ruang Terbuka Kampus UGM, Humanisme dalam Realita Perancangan Arsitektur, UGM 